6. Gaziano JM, Hennekens CH, O'Donnell CJ et al (1997) Fasting triglycerides, high-density lipoprotein, and risk of myocardial infarction. Circulation 96(8):2520-2525

7. Hadaegh F, Khalili D, Ghasemi A et al (2009) Triglyceride/HDL-cholesterol ratio is an independent predictor for coronary heart disease in a population of Iranian men. Nutr Metab Cardiovasc Dis 19(6):401-408

8. Paramsothy P, Katz R, Owens DS et al (2010) Agemodification of lipoprotein, lipid, and lipoprotein ratio-associated risk for coronary artery calcium (from the Multi-Ethnic Study of Atherosclerosis [MESA]). Am J Cardiol 105(3):352-358

9. Bittner V, Johnson BD, Zineh I et al (2009) The TG/ $\mathrm{HDL}$ cholesterol ratio predicts all cause mortality in women with suspected myocardial ischemia a report from the Women's Ischemia Syndrome Evaluation (WISE). Am Heart J 157(3):548-555

10. Kannel WB, Vasan RS, Keyes MJ et al (2008) Usefulness of the triglyceride-high-density lipoprotein versus the cholesterol-high-density lipoprotein ratio for predicting insulin resistance and cardiometabolic risk (from the framingham offspring cohort). Am J Cardiol 101(4):497-501

11. Bertoluci MC, Quadros AS, Sarmento-Leite R et al (2010) Insulin resistance and triglyceride/HDLc index are associated with coronary artery disease. Diabetol Metab Syndr 2:11

12. Gensini GG (1983) A more meaningful scoring system for determining the severity of coronary heart disease. Am J Cardiol 51(3):606

13. Frohlich J, Dobiasova M (2003) Fractional esterification rate of cholesterol and ratio of triglycerides to HDL-cholesterol are powerful predictors of positive findings on coronary angiography. Clin Chem 49(11):1873-1880

14. Krauss RM, Blanche PJ (1992) Detection and quantitation of LDL subfractions. Curr Opin Lipidol 3:377-383

15. Anber V, Griffin BA, McConnell M et al (1996) Influence of plasma lipid and LDL-subfraction profile on the interaction between low density lipoprotein with human arterial wall proteoglycans. Atherosclerosis 24:261-271

16. Zambon A, Austin MA, Brown BG et al (1993) Effect of hepatic lipase on LDL in normal men and those with coronary artery disease. Arterioscler Thromb 13:147-153

17. Hanak V, Munoz J, Teague J et al (2004) Accuracy of the triglyceride to high-density lipoprotein cholesterol ratio for prediction of the low-density lipoprotein phenotype B. Am J Cardiol 94:219-222

18. Ballantyne CM, Olsson AG, Cook TJ et al (2001) Influence of low high-density lipoprotein cholesterol and elevated triglyceride on coronary heart disease events and response to simvastatin therapy in 4S. Circulation 104:3046-3051

19. Voight BF, Peloso GM, Otho-Melander $\mathrm{M}$ et al (2012) Plasma HDL cholesterol and risk of myocardial infarction: a mendelian randomisation study. Lancet 380(9841):572-580

20. Greene DJ, Skeggs JW, Morton RE (2001) Elevated triglyceride content diminishes the capacity of high density lipoprotein to deliver cholesteryl esters via the scavenger receptor class B type I (SRBI). Biol Chem 276:4804-4811

21. Sone H, Tanaka S, Tanaka S et al (2012) Comparison of various lipid variables as predictors of coronary heart disease in Japanese men and women with type 2 diabetes: subanalysis of the Japan diabetes complications study. Diabetes Care
Herz 2014 · 39:110

DOI 10.1007/s00059-013-4016-7

Published online: 16. Februar 2014

(c) Urban \& Vogel 2014

J. Ge - D. Baumgart · M. Haude ·

G. Görge · C. von Birgelen .

S. Sack $\cdot$ R. Erbel

Department of Cardiology, University Essen

\section{Role of intravascular ultrasound imaging in identifying vulnerable plaques}

\author{
Herz (1999) 24:32-41 \\ http://dx.doi.org/10.1007/ \\ BF03043816
}

The authors have retracted this article as it contains large portions of text and figures that have been previously published in Ge J, Chirillo F, Schwedtmann J, Görge G, Haude M, Baumgart D, Shah V, von Birgelen C, Sack S, Boudoulas H, Erbel R (1999) Screening of ruptured plaques in patients with coronary artery disease by intravascular ultrasound. Heart 81:621-627.

\section{Corresponding address}

Prof. Dr. R. Erbel

Department of Cardiology,

University Essen

Hufelandstr. 55, 45147 Essen

Germany

erbel@uk-essen.de 